\title{
Akwizycja obrazu płomienia w wizyjnym systemie diagnostycznym do analizy procesu spalania gazu na palnikach
}

\section{Flame image acquisition in a vision diagnostic system for analyzing the combustion gas process on open-flame burners}

\author{
Maciej Basiura \\ Instytut Nafty i Gazu - Państwowy Instytut Badawczy
}

\begin{abstract}
STRESZCZENIE: W artykule przedstawiono cechy charakterystyczne płomienia powstającego w wyniku spalania paliw gazowych możliwe do zaobserwowania na jego obrazach zarejestrowanych za pomocą różnego rodzaju przetworników wizyjnych i termowizyjnych. Zaprezentowano uproszczony model obrazu płomienia, który jest podstawą oceny jakości spalania gazu na palnikach z płomieniem odkrytym w prowadzonych przez autora badaniach. Opisano wygląd płomienia dyfuzyjnego, kinetyczno-dyfuzyjnego oraz kinetycznego. Podano charakterystyczne cechy obrazów każdego z nich. Zaprezentowane modele odniesiono do równań stechiometrycznych spalania gazów węglowodorowych z użyciem tlenu. Przedstawiono przegląd przeprowadzonych eksperymentów, polegających na zarejestrowaniu obrazów płomienia z wykorzystaniem różnych rodzajów kamer, zarówno termowizyjnych, jak i wizyjnych, tzn. działających w świetle widzialnym. Użyte kamery wyposażone były w przetworniki pracujące w różnych technologiach. Zaprezentowane w artykule termogramy pochodziły z kamer: FLIR GF 320, z detektorem promieniowania podczerwonego typu InSb, FLIR A35, z detektorem typu mikrobolometr, oraz kamery NIT NATIVE WDR ${ }^{\text {TM }}$, z detektorem typu CMOS (SWIR). Stosowane w badaniach kamery wizyjne wyposażone były w przetworniki typu CMOS, CCD. Zwrócono uwagę na problemy występujące podczas rejestracji obrazu płomienia, takie jak prześwietlenia, zbyt duży kontrast, rozmycia, utrata kształtu fotografowanego zjawiska. Przedstawiono parametry przetworników, które mogą wpływać na jakość otrzymywanych zdjęć. Zaprezentowano wyniki eksperymentu polegającego na użyciu cyfrowych algorytmów przetwarzania obrazu w celu zwiększenia na zdjęciu wynikowym jego rozdzielczości i rozpiętości tonalnej oraz osiąganej głębi kolorów (high dynamic range) z serii czterech jednoczesnych zdjęć płomienia. W końcowej części artykułu opisano wyniki eksperymentu polegającego na użyciu filtrów optycznych IR/UV cut i filtrów polaryzacyjnych w celu zmniejszenia prześwietleń i odbić, związanych z dużą jasnością fotografowanego zjawiska fizycznego. We wnioskach skomentowano wyniki przeprowadzonych eksperymentów oraz oceniono wykorzystywane rodzaje filtrów i przetworników zastosowanych kamer pod kątem przydatności do akwizycji obrazów płomieni palników odkrytych.
\end{abstract}

Słowa kluczowe: płomień, rozpoznawanie obrazów, akwizycja obrazów.

ABSTRACT: This article presents the characteristic features of gas flame resulting from gas fuel combustion, which can be seen on its images, registered using various types of vision and thermovision sensors. A simplified model of the flame image is presented, which is the basis for assessing the quality of combustion process on open-flame burners, in the research conducted by the author. The appearance of diffusion, kinetic-diffusion and kinetic flames is described. The characteristic features of each of them are provided. The presented models were referred to stoichiometric equations for the combustion of hydrocarbon gases with oxygen. The paper presents a review of the experiments carried out, consisting of recording flame images using various types of thermal imaging and video cameras. The cameras used were equipped with sensors operating in different technologies. The thermograms presented in the article came from the following cameras: FLIR GF 320 with infrared radiation detector type InSb, FLIR A35 with a microbolometer type detector, and a NIT NATIVE WDR ${ }^{\text {TM }}$ camera equipped with a CMOS detector (SWIR). The video cameras used in the tests were equipped with CMOS and CCD sensors. Attention was paid to problems occurring during flame image acquisition, such as overexposure, too much contrast, blurring, loss of the shape of the photographed phenomenon. The parameters of sensors which could affect the quality of the received images are presented. It presents the results of an experiment applying digital image processing algorithms used in order to increase its tonal range, contrast range and the achieved color depth of the final photograph (High Dynamic Range) from a series of four simultaneous flame images. The final part of the article describes the results of an experiment using IR/UV cut optical filter and polarizing filter to reduce the flashes and reflections associated with the high brightness of the photographed physical phenomenon.

Autor do korespondencji: M. Basiura, e-mail: maciej.basiura@inig.pl

Artykuł nadesłano do Redakcji 29.05.2019 r. Zatwierdzono do druku 21.11.2019 r, 
The conclusions comment on the results of the conducted experiments and the applied types of filters and sensors of the used cameras have been evaluated in terms of their suitability for acquiring images of flames of the open burners.

Key words: flame, image recognition, image acquisition.

\section{Wprowadzenie}

Możliwość sterowania procesami na podstawie ich zarejestrowanych obrazów jest niezaprzeczalna. Najlepszym przykładem są oczy żywych organizmów. Praktycznie wszystkie istoty żywe zostały wyposażone w przetworniki promieniowania umożliwiające im reagowanie na zmieniające się warunki otaczającego świata. Człowiek na podstawie obserwacji zdolny jest do prowadzenia bardzo skomplikowanych działań, w tym bardzo skomplikowanych procesów technologicznych. Faktem jest, że jakość sterowania opartego na obserwacjach zależy od umiejętności operatora, zarówno od predyspozycji fizycznych, wiedzy, jak i wyuczonych umiejętności. Aby móc sterować palnikami z otwartym płomieniem, istnieje potrzeba zdefiniowania płomienia jako zjawiska, które może być zarejestrowane na zdjęciu lub filmie. Czym jest płomień z punktu widzenia „,widzialnego" zjawiska fizycznego i jak może być zarejestrowany jego obraz? Najogólniej mówiąc, płomień jest efektem spalania paliw.

\section{Spalanie paliw gazowych}

Proces spalania jest zbiorem reakcji fizycznych i chemicznych wzajemnie na siebie oddziałujących i warunkujących się nawzajem. Reakcje chemiczne przebiegają między paliwem a utleniaczem, w ściśle określonych przez zachodzące zjawiska fizyczne warunkach. Utleniacz może być dostarczony zarówno do palnika razem z paliwem, jako mieszanka, przed jej zapaleniem, jak również może być pobierany z otoczenia płonącego gazu.

Paliwa kopalne, w tym gazy ziemne, to przede wszystkim związki węgla i wodoru $\left(\mathrm{C}_{\mathrm{m}} \mathrm{H}_{\mathrm{n}}\right)$. Ogólną reakcję ich utleniania można zapisać następującymi równaniami stechiometrycznymi (Kuo, 2005; Kordylewski, 2005).

Spalanie zupełne:

$$
\mathrm{C}_{\mathrm{m}} \mathrm{H}_{\mathrm{n}}+(\mathrm{m}+\mathrm{n} / 4) \mathrm{O}_{2}=\mathrm{mCO}_{2}+\mathrm{n} / 2 \mathrm{H}_{2} \mathrm{O}
$$

Półspalanie:

$$
\mathrm{C}_{\mathrm{m}} \mathrm{H}_{\mathrm{n}}+(\mathrm{m}+\mathrm{n}) / 2 \mathrm{O}_{2}=\mathrm{mCO}+\mathrm{n} / 2 \mathrm{H}_{2} \mathrm{O}
$$

Spalanie niezupełne:

$$
\mathrm{C}_{\mathrm{m}} \mathrm{H}_{\mathrm{n}}+\mathrm{n} / 4 \mathrm{O}_{2}=\mathrm{mC}+\mathrm{n} / 2 \mathrm{H}_{2} \mathrm{O}
$$

W zależności od sposobu wymieszania paliwa z utleniaczem wyróżnia się:
- spalanie dyfuzyjne - występuje przy braku wstępnego wymieszania paliwa z utleniaczem;

- spalanie kinetyczno-dyfuzyjne - to rodzaj spalania, w których paliwo gazowe jest wstępnie zmieszane $\mathrm{z}$ utleniaczem w stopniu niewystarczającym do realizacji zupełnego spalania. W związku z tym proces rozłożony jest na dwa etapy. W pierwszym etapie zachodzi niepełne spalanie kinetyczne, w drugim natomiast - spalanie dyfuzyjne resztek paliwa z utleniaczem doprowadzonym z otoczenia;

- spalanie kinetyczne - spalanie jednorodnej mieszaniny paliwa (gazu lub par) z utleniaczem, zachodzi przy ustalonym współczynniku nadmiaru utleniacza oraz w ustalonej temperaturze.

Największy wpływ na ukształtowanie się płomienia przy spalaniu paliwa gazowego ma regulacja stosunku utleniacza w mieszance do ogólnej ilości utleniacza potrzebnego do spalania. Więcej na temat procesu spalania oraz różnych rodzajów płomienia można znaleźć w następujących pracach: Kuo, 2005; Kordylewski, 2005; Wojtowicz, 2010, 2011, 2013, 2016.

$\mathrm{W}$ opisanych poniżej eksperymentach do spalania paliw węglowodorowych jako utleniacz stosowano tlen. W zależności od konstrukcji używanych palników korzystano z tlenu zawartego w powietrzu, a także z czystego sprężonego tlenu. W związku z tym w dalszej części artykułu pojęcie utleniacza utożsamiane jest $\mathrm{z}$ tlenem.

Z wzorów (1), (2), (3) wyciągnąć można następujące wnioski: - przy braku tlenu w mieszance płomień będzie typowo dyfuzyjny. W zależności od konstrukcji palnika, a także kinetyki procesu w spalinach mogą pojawić się nieprzereagowane substancje palne, w tym węglowodory oraz tlenek węgla (II);

- jeśli stosunek tlenu do paliwa (spalanego gazu węglowodorowego) w mieszance będzie od 0 do $(m+n / 4)$, to płomień będzie kinetyczno-dyfuzyjny;

- jeśli stosunek tlenu do paliwa (spalanego gazu węglowodorowego) w mieszance będzie większy lub równy $(m+n / 4)$, to płomień będzie typowo kinetyczny.

W zależności od ilości dostarczonego do procesu spalania utleniacza wyróżnić można następujące rodzaje mieszanek:

- bogatą - nadmiar paliwa, niedomiar utleniacza;

- stechiometryczną - skład mieszanki palnej odpowiedni do zajścia reakcji całkowitego spalania;

- ubogą - nadmiar utleniacza, niedomiar paliwa.

Stosunek tlenu do paliwa w mieszance może być wykorzystywany do określania rodzaju płomienia. Tym samym może stanowić wskaźnik jakości rodzaju płomienia. 


\section{Płomień}

Na podstawie przeprowadzonych przez autora eksperymentów opracowano model płomienia, który umożliwia zdefiniowanie poszczególnych jego stref obserwowanych na zdjęciach i filmach rejestrowanych za pomocą urządzeń technicznych.

Na potrzeby obecnych rozważań za „płomień” przyjmuje się zjawisko wypromieniowania energii w postaci fal elektromagnetycznych w efekcie gwałtownej, egzotermicznej reakcji utleniania. To właśnie zarejestrowany przez urządzenie techniczne obraz wypromieniowanych fal elektromagnetycznych będzie nazywany płomieniem. Takie przyjęcie definicji płomienia prowadzi do traktowania zjawiska zgodnie z intuicją, bez ograniczenia go przy tym do zjawiska zachodzącego wyłącznie w zakresie światła widzialnego. Tak zdefiniowane zjawisko zachodzi zawsze podczas procesu spalania paliw w tlenie.

Biorąc pod uwagę powyższe rozważania oraz teorię na temat spalania (Kuo, 2005; Kordylewski, 2005), opracowano uproszczony model obrazu płomienia. Przedstawione poniżej strefy płomienia nie są tożsame ze strefami (stożkami) płomienia opisywanymi w literaturze. Wynika to z faktu - omówionego w dalszej części opracowania - że obraz zjawiska, jakim jest płomień, zależy od urządzeń stosowanych do jego rejestracji (rys. 4).

Uproszczony podział płomieni:

- płomień typowo dyfuzyjny, który jest wrażliwy na każdą najmniejszą zmianę warunków, np. warunków otoczenia (ruchy powietrza wokół płomienia);

- płomień kinetyczno-dyfuzyjny - stabilny płomień z widoczną częścią dyfuzyjną, której zachowanie jest okresowe;

- płomień kinetyczny - stabilny płomień niewrażliwy na zmiany warunków - np. płomień spawalniczych palników acetylenowo-tlenowych, przy odpowiednim ustawieniu ilości paliwa i tlenu.

\section{Płomień dyfuzyjny}

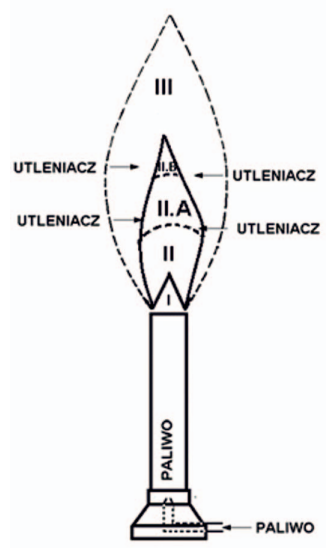

Rys. 1. Model obrazu płomienia dyfuzyjnego

Fig. 1. Model of the diffusion flame image
Strefy płomienia dyfuzyjnego:

I. Strefa ciemna - jest to strefa, w której nie następuje jeszcze zapłon mieszanki paliwowej, ponieważ energia dostarczana z następnych stref jest niewystarczająca do inicjacji reakcji zapłonu mieszanki, mieszanka palna nie osiąga temperatury zapłonu lub w przestrzeni nie istnieje mieszanka palna, mieszanka paliwa $\mathrm{z}$ utleniaczem $\mathrm{z}$ otoczenia nie przekroczyła granicy zapłonu. Wielkość tej strefy zależy m.in. od prędkości dyfuzji utleniacza w paliwie oraz prędkości wypływu paliwa.

II. Stożek (spalania dyfuzyjnego) - obszar spalania powstałej mieszanki. Strefa jest widoczna w świetle widzialnym.

II.A. Strefa zmiany koloru płomienia - na skutek zbyt małej prędkości dyfuzji utleniacza lub niewystarczającej energii podtrzymującej reakcję dochodzi do zmiany koloru świecenia płomienia na kolor o większej długości fali, mniejszej temperaturze.

II.B. Strefa turbulencji - w obszarze tym obserwuje się zjawisko odrywania się płomienia. Turbulencje występują, gdy okresowo brakuje utleniacza.

III. Produkty spalania - obszar produktów spalania; w przypadku płomienia dyfuzyjnego strefa rzadko będzie widoczna w świetle widzialnym. Strefa ta jest dobrze widoczna na zdjęciach w podczerwieni (Basiura, 2014).

\section{Płomień kinetyczno-dyfuzyjny}

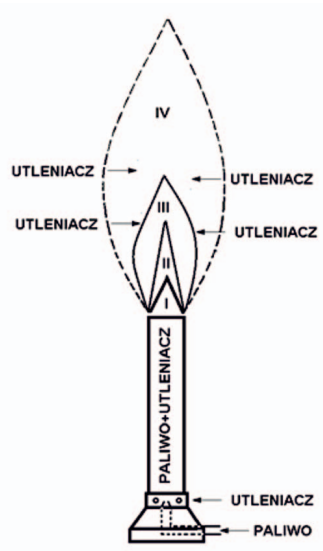

Rys. 2. Model obrazu płomienia kinetyczno-dyfuzyjnego

Fig. 2. Model of the kineticdiffusion flame image

Strefy płomienia kinetyczno-dyfuzyjnego:

I. Strefa ciemna - jest to strefa, w której nie następuje jeszcze zapłon mieszanki paliwowej, ponieważ energia dostarczana z następnych stref jest niewystarczająca do inicjacji reakcji zapłonu mieszanki lub w przestrzeni nie istnieje mieszanka palna. Wielkość strefy ciemnej zależy m.in. od prędkości spalania oraz od prędkości wypływu mieszanki. Prędkość spalania ściśle zależy od rodzaju paliwa i rodzaju utleniacza (tj. składu mieszanki paliwowej).

II. Stożek (spalania kinetycznego) - obszar spalania; do 
podtrzymania reakcji w tej strefie nie ma konieczności dostarczania utleniacza z otoczenia płomienia. Strefa jest widoczna w świetle widzialnym.

III. Drugi stożek (spalania dyfuzyjnego) - obszar dopalania dyfuzyjnego produktów niezupełnego spalania ze strefy II oraz niespalonego paliwa. Do reakcji potrzebny jest utleniacz z otoczenia. Strefa jest widoczna w świetle widzialnym.

IV. Produkty spalania - obszar produktów spalania. Strefa jest widoczna w świetle widzialnym, jeśli reakcja spalania zachodzi w wysokiej temperaturze, wystarczającej do rozgrzania spalin.

\section{Płomień kinetyczny}

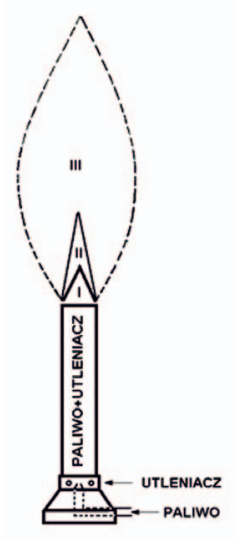

Rys. 3. Model obrazu płomienia kinetycznego

Fig. 3. Model of the kinetic flame image

Strefy płomienia kinetycznego:

I. Strefa ciemna - jest to strefa, w której nie następuje jeszcze zapłon mieszanki paliwowej, ponieważ energia dostarczana z następnych stref jest niewystarczająca do inicjacji reakcji zapłonu mieszanki lub w przestrzeni nie istnieje mieszanka palna. Wielkość strefy ciemnej zależy m.in. od prędkości spalania oraz od prędkości wypływu mieszanki. Prędkość spalania ściśle zależy od rodzaju paliwa i rodzaju utleniacza (tj. składu mieszanki paliwowej).

II. Stożek (spalania kinetycznego) - obszar spalania; do podtrzymania reakcji w tej strefie nie ma konieczności dostarczania utleniacza z otoczenia płomienia. Strefa jest widoczna w świetle widzialnym.

III. Produkty spalania - obszar produktów spalania. Strefa jest widoczna $\mathrm{w}$ świetle widzialnym, jeśli reakcja spalania zachodzi w wysokiej temperaturze, wystarczającej do rozgrzania spalin.

Uproszczony model obrazów płomieni wydaje się odpowiedni do większości zastosowań, zarówno do oceny procesu spalania gazów palnych na palnikach otwartych, jak też w procesach technologicznych takich jak spawanie i lutowanie za pomocą palników gazowych. Cyganek i Basiura (2017) z powodzeniem wyodrębnili poszczególne strefy płomienia palników spawalniczych. Wydaje się również możliwe zastosowanie powyższego, uproszczonego modelu do oceny spalania gazu procesowego we flarach i pochodniach. Zmiana sposobu palenia flary z dyfuzyjnego na kinetyczno-dyfuzyjny skutkować będzie zmniejszeniem emisji tlenku węgla(II) oraz niedopalonych związków węglowodorowych do atmosfery. Pozwoli to na zredukowanie emisji gazów cieplarnianych w procesach wydobycia ropy naftowej itp.

\section{Komputerowy system rozpoznawania obrazu}

Metody rozpoznawania obrazów utożsamiane są tylko i wyłącznie z metodami rozpoznawania obiektów na fotografii bądź filmie, ogólnie na obiektach graficznych, niemniej jednak metody te odnoszą się do wszystkich zagadnień związanych $\mathrm{z}$ rozpoznawaniem wzorców w dowolnych sygnałach. Mogą to być przebiegi czasowe z czujników, rozkłady wartości mierzonych (np. temperatury), nagrania audio, jak również obrazy graficzne, fotografie i filmy, a także inne zdigitalizowane zbiory danych. Więcej na ten temat można znaleźć w opracowaniach Cyganka (2013) oraz Tadeusiewicza i Flasińskiego (1991). Na podstawie cytowanych pozycji można w sposób bardziej precyzyjny określić metody „rozpoznawania obrazów” jako dotyczące „rozpoznawania wzorców”; w literaturze anglojęzycznej funkcjonująca nazwa tego zagadnienia to pattern recognition.

$\mathrm{W}$ prowadzonych badaniach zrejestrowanym sygnałem był obraz płomienia palników z otwartym płomieniem. W początkowych eksperymentach stosowano inżektorowy palnik na gaz ziemny, w późniejszych natomiast inżektorowe palniki na propan-butan techniczny oraz palniki gazowo-tlenowe: propano-butanowo-tlenowe, acetylenowo-tlenowe.

Akwizycja obrazu jest bardzo ważnym etapem całego procesu. Nie wszystkie błędy i niedociągnięcia tego etapu można wyeliminować, stosując cyfrową obróbkę i przetwarzanie. Wybór odpowiedniej kamery też nie jest zadaniem prostym. Pomimo mnogości dostępnych rozwiązań należy wziąć pod uwagę szereg czynników. Nie należy się przy tym spodziewać, że zarejestrowany przez urządzenie techniczne obraz będzie identyczny jak obraz widziany przez człowieka.

Wykonywanie zdjęć płomienia przypomina wykonywanie zdjęć jasnych gwiazd, np. zdjęć Słońca (Convington, 2018), w zakresie problemów z zakresem tonalnym, odwzorowaniem kolorów, a także problemami związanymi z zanieczyszczeniem światłem fotografowanej sceny (Popowicz, 2011a, 2011b; Kossowski i Stasiński, 2012). Zanieczyszczenia mogą pochodzić bezpośrednio od fotografowanego procesu, jak również z innych, niezależnych źródeł (Kołomański, 2012). Główną 
różnicą jest szybkość zmian obrazu płomienia, która uniemożliwia zastosowanie standardowych technik wykorzystywanych w fotografii i astrofotografii. Na rynku dostępne są różne światłoczułe przetworniki. W kamerach termowizyjnych najczęściej stosowane są przetworniki InSb lub bolometryczne, w aparatach fotograficznych - przetworniki CMOS lub CCD. W artykułach Kruczka (2013) oraz Parzycha i in. (2017) autorzy analizują właściwości poszczególnych przetworników.

\section{Parametry przetwornika obrazu kamery wpływające na jakość zarejestrowanego obrazu}

Rozdzielczość rejestrowanego obrazu musi być dobrana do rejestrowanego obiektu (zjawiska). Przetwornik musi zapewniać odpowiedni obszar rejestracji, jednocześnie zachowując szczegółowość wystarczającą do wyeksponowania indywidualnych cech rejestrowanego obiektu.

Biorąc pod uwagę liczbę rejestrowanych kolorów, rozróżnia się dwa podstawowe rodzaje przetworników: kolorowy i monochromatyczny. Do niektórych zastosowań przetworniki monochromatyczne są w zupełności wystarczające. Często kolejne etapy cyfrowego przetwarzania przekształcają zarejestrowane kolorowe obrazy na postać monochromatyczną lub nawet binarną. W tak skonstruowanych algorytmach z powodzeniem można zastosować kamery z przetwornikami monochromatycznymi. Również kamery termowizyjne wykonują zdjęcia radiometryczne, które są monochromatyczne. Kolory na termogramach stanowią wynik obróbki cyfrowej i są dobierane według indywidualnych upodobań operatora.

Istotnym parametrem, który wpływa na rodzaj otrzymanego obrazu, jest zakres fal elektromagnetycznych, w którym przetwornik wykazuje czułość. W innym zakresie fal działają kamery światła widzialnego, kamery termowizyjne lub kamery ultrafioletu.

Do rejestracji zdjęć stosuje się przeważnie zakres fal elektromagnetycznych zwanych falami świetlnymi. Umowne granice zakresu przyjmuje się dla długości fal od 0,03 $\mathrm{mm}$ do $5 \mathrm{~nm}$ oraz dzieli się go na podzakresy (Lipczyński et al., 1984): - podczerwień (IR) - długość fali od 0,03 $\mathrm{mm}$ do $790 \mathrm{~nm}$; - Śsiatło widzialne - długość fali od $790 \mathrm{~nm}$ do $390 \mathrm{~nm}$; - nadfiolet (UV) - długość fali od $390 \mathrm{~nm}$ do $5 \mathrm{~nm}$.

Oczywiście granice zakresów i podzakresów są orientacyjne i umowne. W zależności od dziedziny zastosowania lub analizowanych skutków działania jako granice podzakresów mogą być przyjmowane inne długości fal. Większość przetworników światła widzialnego działa również w obrębie bliskiej podczerwieni i ultrafioletu. W celu ograniczenia zakresu rejestrowanych fal lub osiągnięcia zamierzonych efektów na rejestrowanym obrazie stosować należy filtrację. Część efektów można osiągnąć poprzez użycie fizycznych filtrów optycznych, np. ograniczenie zakresu promieniowania na detektor, polaryzację padającego światła, użycie kolorowych filtrów itp. Niektóre efekty można uzyskać przez odpowiednią konstrukcję lub konfigurację pracy stosowanego detektora, np. filtrację barwną, tj. osiągnięcie na obrazie dominanty jednego z kolorów można zrealizować poprzez zwiększenie czułości części pikseli odpowiadających za rejestrację wybranego koloru.

Ważnymi parametrami przetworników obrazu są: rozdzielczość tonalna, rozpiętość tonalna i głębia koloru. Rozdzielczość tonalna to zdolność układu rejestracji do reprodukcji zmian intensywności w rejestrowanym obrazie. Rozpiętość tonalna to parametr mówiący o możliwej do osiągnięcia różnicy pomiędzy najjaśniejszym a najciemniejszym obszarem rejestrowanego obrazu, świadczy o możliwościach przetwornika do rejestracji detali kontrastowych obiektu na obrazie. Głębia koloru to natomiast liczba bitów wykorzystywanych do reprezentacji koloru danego piksela i oznacza liczbę możliwych do uzyskania kolorów. Niestety obecnie komercyjnie dostępne przetworniki nie zbliżyły się jeszcze do możliwości oka ludzkiego w zakresie rozdzielczości i rozpiętości tonalnej oraz rejestrowanej głębi koloru, ale istnieje możliwość użycia technik przetwarzania obrazu, które niwelują niedoskonałości przetworników. Techniki i algorytmy zwiększania zakresu tonalnego oraz barwnego fotografii można określić wspólną nazwą technologii HDR (high dynamic range). Technologia ta umożliwia wykonanie zdjęcia, którego parametry są zbliżone do parametrów obrazu rejestrowanego przez ludzkie oko, tzn. pozwala na przedstawienie na jednym obrazie kontrastowych szczegółów fotografowanego obiektu. Ostatnim parametrem przetwornika światłoczułego, który wydaje się parametrem kluczowym z punktu widzenia rejestracji szybkozmiennych, zwłaszcza w fotografowaniu obiektów będących źródłem promieniowania, jest stosowana technologia działania migawki. W sensorach światłoczułych wykorzystuje się dwie podstawowe technologie odczytu wartości poszczególnych pikseli. Rolling shutter to metoda przechwytywania obrazu, w której matryca jest naświetlana i odczytywana w sposób ciągły. Odczytywana jest jedna linia naraz, po kolei z góry na dół. Ta metoda pracy migawki skutkuje powstawaniem artefaktów na obrazie, np. na skutek szybkiego ruchu fotografowanego obiektu lub zjawiska fizycznego. W metodzie global shutter wszystkie piksele matrycy jednocześnie rozpoczynają i kończą naświetlanie. Migawka otwiera się w określonym czasie, a następnie zamyka, blokując padanie światła na elementy światłoczułe czujnika. Dzięki migawce global shutter uzyskuje się ostre obrazy procesów szybkozmiennych. Możliwe jest ustawianie bardzo krótkich czasów naświetlania, co może być dodatkowym atutem podczas fotografowania obiektów lub procesów świecących intensywnym światłem. 


\section{Kamery termowizyjne}

W pierwszym etapie do rejestracji użyto przede wszystkim kamer termowizyjnych. Ze względu na temperaturę generowaną przez płomień oraz jego parametry radiacyjne (Gebhardt, 1983; Nadziakiewicz, 1989) sprawdzono możliwości rejestracji obrazów płomienia za pomocą kamer termowizyjnych. Dokładny opis przeprowadzonych eksperymentów można znaleźć w publikacjach autora niniejszego artykułu (Basiura 2014, 2015). Ważnym parametrem w termowizji umożliwiającym analizowanie rozkładu temperatury na obserwowanej scenie poszczególnych obiektów jest emisyjność tych obiektów. Emisyjność płomienia jest bardzo niska i zmienna w różnych jego częściach, co uniemożliwia poprawne wnioskowanie o właściwej temperaturze danej strefy płomienia. Problem ten został poruszony w pracach Gebhardta (1983) i Nadziakiewicza (1989), poświęconym radiacyjnej naturze płomienia. Prace te zwracają uwagę na niską emisyjność płomienia, ale traktują ją jako emisyjność całkowitą, natomiast kamery termowizyjne, działając w swoich pasmach promieniowania podczerwonego, korzystają niejako z emisyjności pasmowej, która może się różnić od emisyjności całkowitej.

Wojtowicz w swoich opracowaniach $(2010,2013,2016)$ porusza problem jakości spalania w urządzeniach domowego użytku w zależności od składu paliwa (gazu). Analizując wyniki wyżej wymienionych, do pierwszego etapu badań wybrano gaz ziemny wysokometanowy (gaz z sieci przesyłowej). częstotliwości, w których największą wartość absorpcji i emisji mają związki najpowszechniej występujące w powietrzu, w tym również para wodna i tlenek węgla(IV). Te dwa związki chemiczne są głównymi składnikami spalin płomieni powstających ze spalania węglowodorów. Dlatego obrazy płomieni rejestrowane w podczerwieni za pomocą kamer termowizyjnych są niejako zniekształcone, gdyż brak w nich promieniowania charakterystycznego właśnie dla tych dwóch związków. Termogramy płomieni niosą za sobą wiele informacji, które nie są widoczne w świetle widzialnym. Na termogramach wyraźnie widać strefy wysokiej temperatury wychodzące daleko poza widzialny obrys płomienia. Wielkość widocznych stref zależy od ustawień kamery i zakresu rejestrowanego widma. $\mathrm{Z}$ powodu zasady działania kamery termowizyjnej, tzn. rejestracji promieniowania temperaturowego z powierzchni badanego obiektu, płomień na termogramie nie jest obiektem półprzeźroczystym, jak w świetle widzialnym. Niemożliwa jest więc ocena wewnętrznych stożków płomienia. Na podstawie wniosków po pierwszym etapie eksperymentów oceniono, że kamery wizyjne dużo lepiej nadają się do oceny płomieni niż kamery termograficzne. Eksperci oceniający jakość płomienia (np. spawacze) kryteria oceny budują na podstawie obrazów płomieni w świetle widzialnym.

Do kolejnych eksperymentów używano palników gazowotlenowych, których zasada działania pozwala na pomiar i kontrolę ilości utleniacza w mieszance. Do pomiarów ilości przepływających gazów wykorzystano termiczne przepływomierze
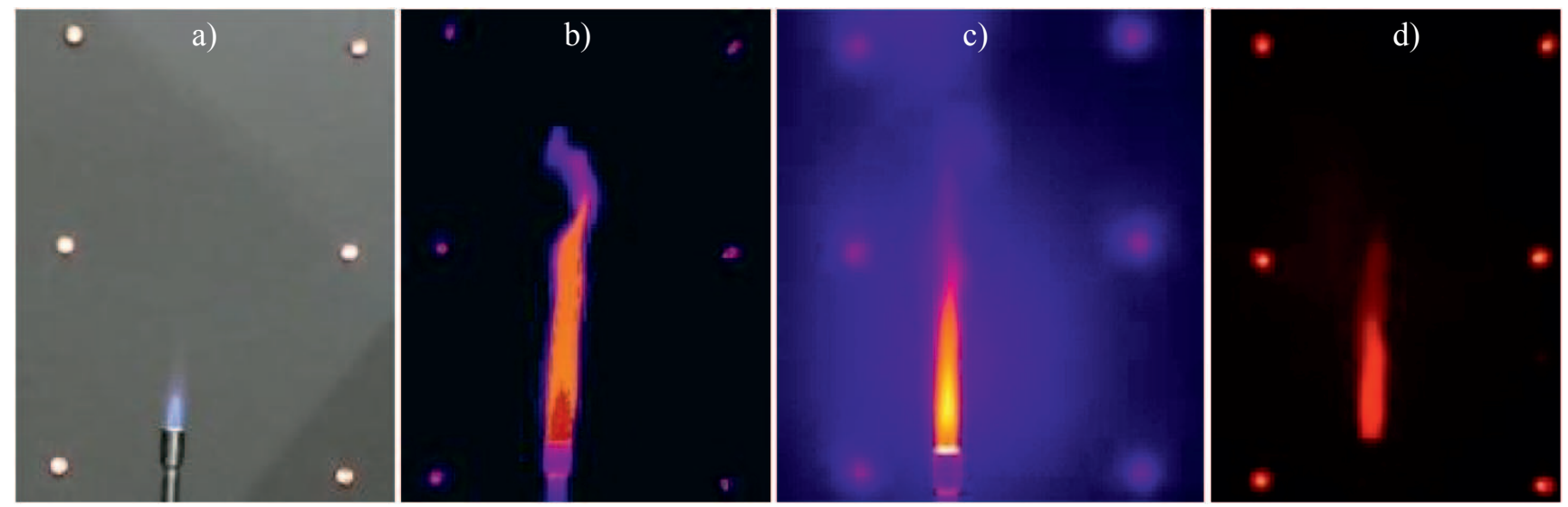

Rys. 4. Obraz płomienia w różnych zakresach fal elektromagnetycznych: a) promieniowanie widzialne; b) promieniowanie podczerwone z zakresu 3,2-3,4 $\mu$ m (FLIR GF 320); c) promieniowanie podczerwone z zakresu 7,5-13 $\mu \mathrm{m}$ (FLIR A35); d) promieniowanie podczerwone z zakresu 0,9-1,7 $\mu \mathrm{m}$ (NIT NATIVE WDR ${ }^{\mathrm{TM}}$ )

Fig. 4. Image of the flame in different spectra of electromagnetic waves: a) visible radiation; b) infrared radiation in the range from 3.2 to $3.4 \mu \mathrm{m}$ (FLIR GF320); c) infrared radiation in the range from 7.5 to $13 \mu \mathrm{m}$ (FLIR A35); d) radiation infrared range from 0.9 to $1.7 \mu \mathrm{m}$ (NIT NATIVE WDR ${ }^{\mathrm{TM}}$ )

Niestety wszystkie obecnie produkowane kamery termowizyjne są przygotowane w taki sposób, aby działały w zakresach fal, w których transmisja przez atmosferę jest jak największa. Z zakresu działania kamer wycięte są w związku z tym te masowe. Wybór metody pomiarowej był podyktowany stosowaniem tego typu przepływomierzy w pracy laboratoryjnej Zakładu Użytkowania Paliw Instytutu Nafty i Gazu Państwowego Instytutu badawczego (Siuda, 2014). 


\section{Sprawdzenie możliwości rejestracji płomienia za pomocą sekwencji obrazów}

Nawet gołym okiem widać, że płomień jest zmienny w czasie. Im płomień ma charakter bardziej dyfuzyjny, tym bardziej niestacjonarny jest jego obraz. Stacjonarność płomienia sprawdzono, wykonując rejestrację jego obrazu za pomocą aparatu Nikon COOLPIX AW130 z prędkością 25 klatek na sekundę.

Rysunek 5 prezentuje 10 kolejnych klatek z rejestracji stabilnie palącego się palnika.

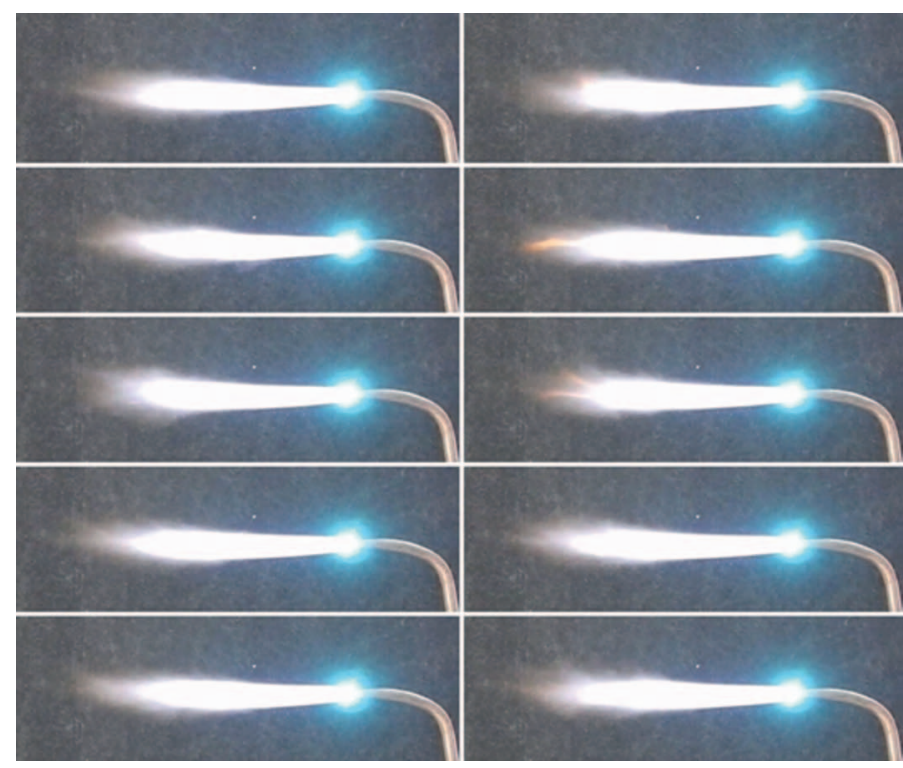

Rys. 5. 10 kolejnych klatek zarejestrowanych za pomocą aparatu Nikon COOLPIX AW130

Fig. 5. 10 consecutive frames captured with a Nikon COOLPIX AW130

Na zarejestrowanych klatkach widać, że kształt i kolor obrazu płomienia się zmieniają, zwłaszcza w obrębie stożka dyfuzyjnego i w strefie produktów spalania.

Na obrazach płomienia acetylenowo-tlenowego widać artefakty powstające z powodu małej rozdzielczości tonalnej i rozpiętości tonalnej przetwornika kamery. Kontrastowość fotografowanego obiektu (jest mocno prześwietlony), a także głębia kolorów wykonanych zdjęć są znikome. Stwierdzono, że do wykonywania zdjęć płomienia odpowiednia będzie technika HDR. Biorąc pod uwagę niestacjonarność obrazu płomienia w czasie, wykonanie sekwencji zdjęć pojedynczym aparatem (przetwornikiem), przestrajając ustawienia (np. ekspozycji, przesłony itp.) pomiędzy kolejnymi zdjęciami, spowoduje zatarcie szczegółów związanych z kształtem i wymiarami płomienia oraz utrudni jego klasyfikację. Głównie z tego powodu zaplanowano kolejny eksperyment, w którym wykorzystano cztery niezależne przetworniki do rejestracji obrazów oraz opomiarowano gazy zasilające palnik w celu identyfikacji rodzaju płomienia. Opis systemu, za pomocą którego prowadzono eksperymenty, oraz więcej zdjęć płomieni różnych rodzajów palników można znaleźć w opracowaniu autora niniejszego artykułu (Basiura, 2017).

Do eksperymentów z użyciem technik i algorytmów HDR wykorzystano komercyjny program Machinery HDR Effects. Do wykonania obrazów złożonych wykorzystano cztery fotografie płomienia zarejestrowane przez system w tym samym momencie (rys. 6), przy różnym ustawieniu poszczególnych przetworników. W pierwszej kolejności testowano jakość łączenia zdjęć i algorytmy umożliwiające niwelację efektów związanych z geometrycznym przesunięciem przetworników i usuwanie artefaktów (tzw. duchów) na zdjęciu o zwiększonym zakresie dynamiki (wynikowym).

Do zaprezentowania wyników wybrano zestaw obrazów płomienia (rys. 6) nieposiadający dużych prześwietlonych powierzchni, na którym da się zaobserwować różnicę stref płomienia pomiędzy klatkami. Na potrzeby testów wykonano również ręczne kadrowanie wybranego zestawu fotografii (rys. 7). Wyniki działania algorytmów zaprezentowano na rysunkach 8-13.

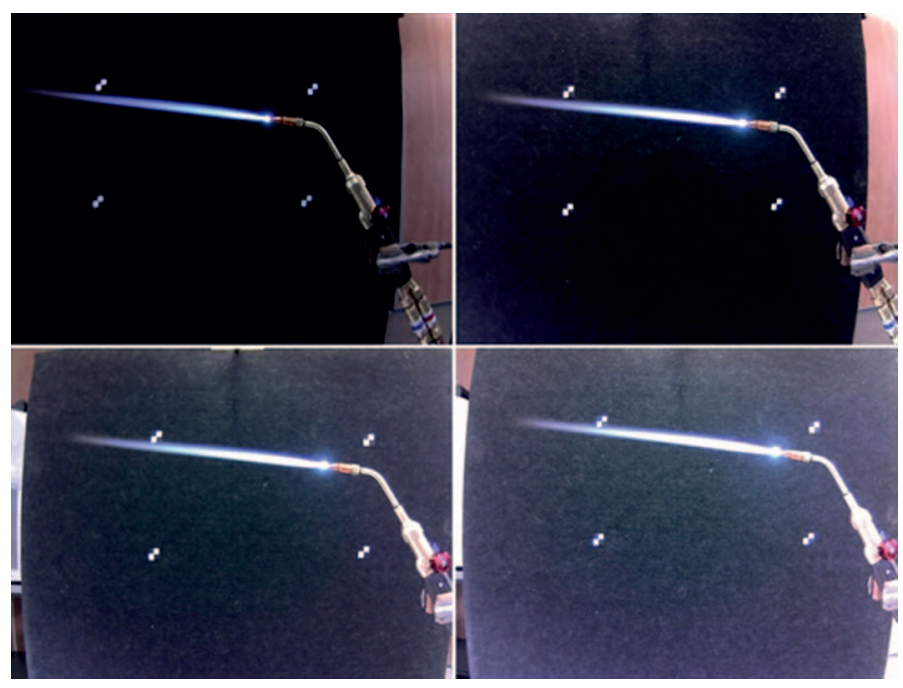

Rys. 6. Zdjęcia płomienia - stosunek ilości tlenu do gazu palnego: $\frac{\mathrm{O}_{2}}{\mathrm{C}_{2} \mathrm{H}_{2}}=7,5$

Fig. 6. Photos of the flame - the ratio of oxygen to fuel gas: $\frac{\mathrm{O}_{2}}{\mathrm{C}_{2} \mathrm{H}_{2}}=7.5$

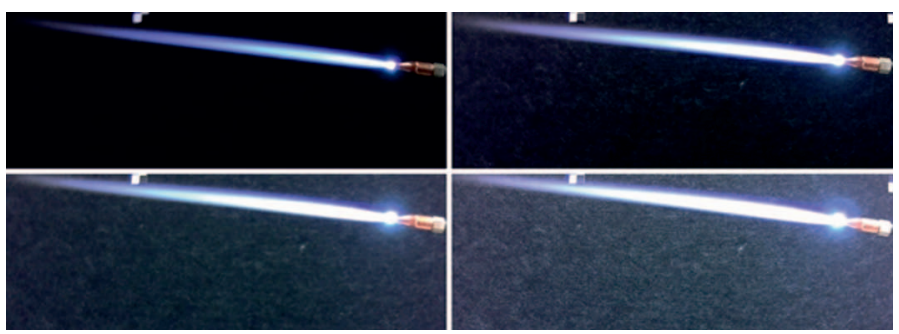

Rys. 7. Wykonane kadrowanie fotografii płomienia dla zestawu zdjęć $\mathrm{z}$ rysunku 6

Fig. 7. Framing flame photography for a set of photos from Figure 6 


\section{artykuły}
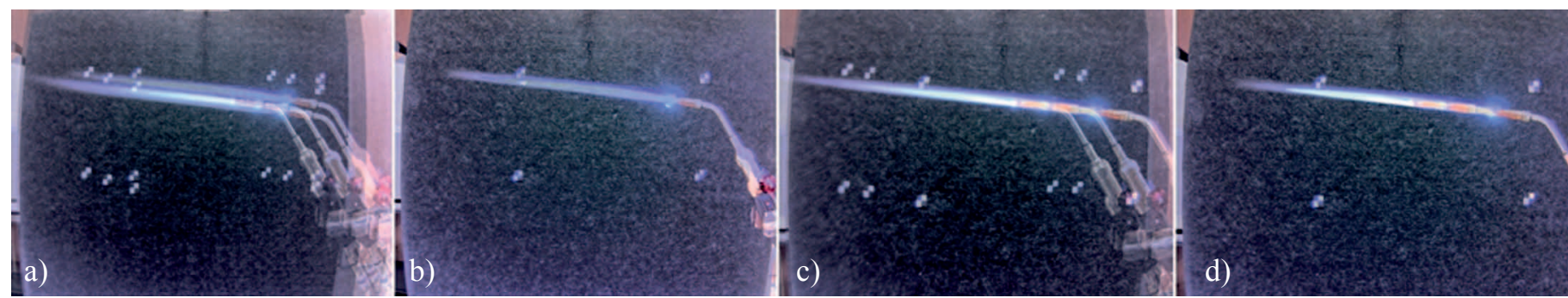

Rys. 8. Obrazy HDR wykonane na podstawie zestawu zdjęć z rysunku 6, łączenie obrazów algorytmem NATURALNY HDR, opcje: a) wyłączone usuwanie duchów, wyłączone wyrównanie obrazów; b) włączone usuwanie duchów, wyłączone wyrównanie obrazów; c) wyłączone usuwanie duchów, włączone wyrównanie obrazów; d) włączone usuwanie duchów, włączone wyrównanie obrazów

Fig. 8. HDR images made on the basis of a set of photos from Figure 6, combining images NATURAL HDR algorithm, options: a) ghost removal disabled, image alignment disabled; b) ghost removal enabled, image alignment disabled; c) ghost removal disabled, image alignment enabled; d) ghost removal enabled, image alignment enabled
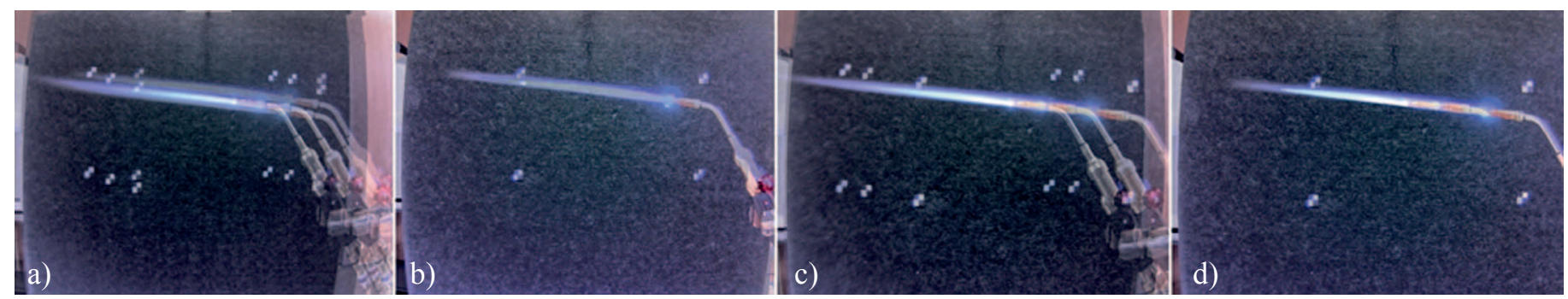

Rys. 9. Obrazy HDR wykonane na podstawie zestawu zdjęć z rysunku 6, łączenie obrazów algorytmem DETEKCJA KONTRASTU, opcje: a) wyłączone usuwanie duchów, wyłączone wyrównanie obrazów; b) włączone usuwanie duchów, wyłączone wyrównanie obrazów; c) wyłączone usuwanie duchów, włączone wyrównanie obrazów; d) włączone usuwanie duchów, włączone wyrównanie obrazów

Fig. 9. HDR images made on the basis of a set of photos from Figure 6, combining images algorithm CONTRAST DETECTION, options: a) ghost removal disabled, image alignment disabled; b) ghost removal enabled, image alignment disabled; c) ghost removal disabled, image alignment enabled; d) ghost removal enabled, image alignment enabled
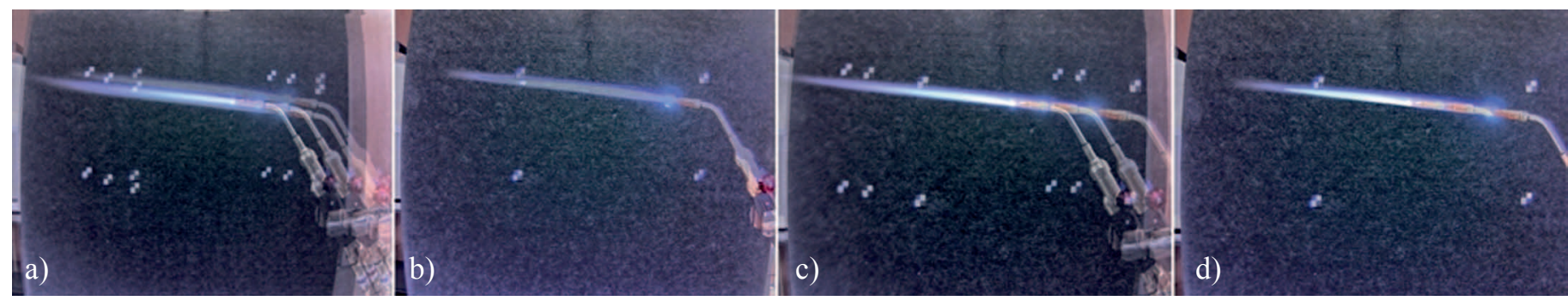

Rys. 10. Obrazy HDR wykonane na podstawie zestawu zdjęć z rysunku 6, łączenie obrazów algorytmem DETEKCJA KRAWĘDZI, opcje: a) wyłączone usuwanie duchów, wyłączone wyrównanie obrazów; b) włączone usuwanie duchów, wyłączone wyrównanie obrazów; c) wyłączone usuwanie duchów, włączone wyrównanie obrazów; d) włączone usuwanie duchów, włączone wyrównanie obrazów

Fig. 10. HDR images made on the basis of a set of photos from Figure 6, combining images algorithm EDGE DETECTION, options: a) ghost removal disabled, image alignment disabled; b) ghost removal enabled, image alignment disabled; c) ghost removal disabled, image alignment enabled; d) ghost removal enabled, image alignment enabled
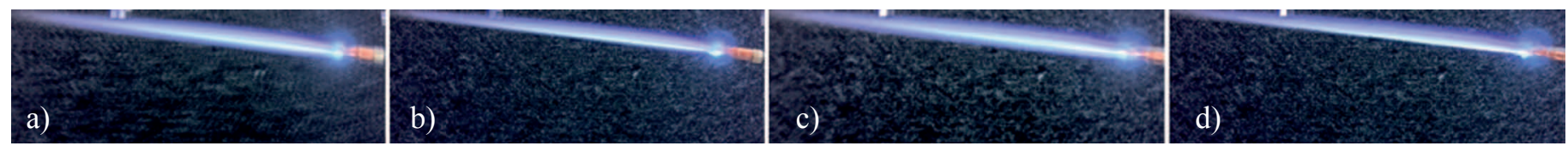

Rys. 11. Obrazy HDR wykonane na podstawie kadrowanego zestawu zdjęć z rysunku 7, łączenie obrazów algorytmem NATURALNY HDR, opcje: a) wyłączone usuwanie duchów, wyłączone wyrównanie obrazów; b) włączone usuwanie duchów, wyłączone wyrównanie obrazów; c) wyłączone usuwanie duchów, włączone wyrównanie obrazów; d) włączone usuwanie duchów, włączone wyrównanie obrazów

Fig. 11. HDR images made on the basis of a cropped set of photos from Figure 7, combining images NATURAL HDR algorithm, options: a) ghost removal disabled, image alignment disabled; b) ghost removal enabled, image alignment disabled; c) ghost removal disabled, image alignment enabled; d) ghost removal enabled, image alignment enabled 

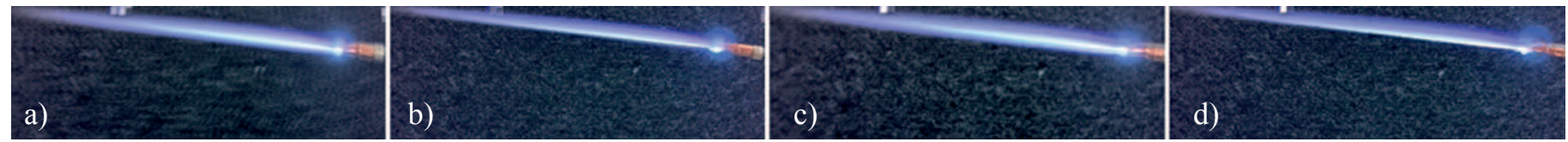

Rys. 12. Obrazy HDR wykonane na podstawie kadrowanego zestawu zdjęć z rysunku 7, łączenie obrazów algorytmem DETEKCJA KONTRASTU, opcje: a) wyłączone usuwanie duchów, wyłączone wyrównanie obrazów; b) włączone usuwanie duchów, wyłączone wyrównanie obrazów; c) wyłączone usuwanie duchów, włączone wyrównanie obrazów; d) włączone usuwanie duchów, włączone wyrównanie obrazów

Fig. 12. HDR images made on the basis of a cropped set of photos from Figure 12, combining images algorithm CONTRAST DETECTION, options: a) ghost removal disabled, image alignment disabled; b) ghost removal enabled, image alignment disabled; c) ghost removal disabled, image alignment enabled; d) ghost removal enabled, image alignment enabled
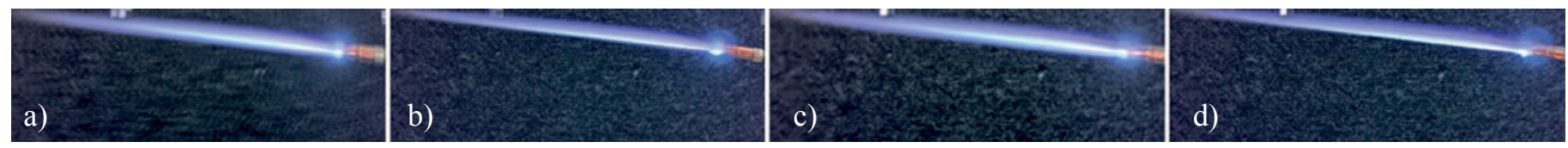

Rys. 13. Obrazy HDR wykonane na podstawie kadrowanego zestawu zdjęć z rysunku 7, łączenie obrazów algorytmem DETEKCJA KRAWĘDZI, opcje: a) wyłączone usuwanie duchów, wyłączone wyrównanie obrazów; b) włączone usuwanie duchów, wyłączone wyrównanie obrazów; c) wyłączone usuwanie duchów, włączone wyrównanie obrazów; d) włączone usuwanie duchów, włączone wyrównanie obrazów

Fig. 13. HDR images made on the basis of a cropped set of photos from Figure 7, combining images algorithm EDGE DETECTION, options: a) ghost removal disabled, image alignment disabled; b) ghost removal enabled, image alignment disabled; c) ghost removal disabled, image alignment enabled; d) ghost removal enabled, image alignment enabled

Analizując fotografie z poszczególnych kamer, można zauważyć widoczne obszary prześwietleń, wynikające zapewne z niewystarczającej rozdzielczości tonalnej przetworników, jak również ze sposobu działania migawki (rolling shutter). Próby zwiększenia rozdzielczości tonalnej za pomocą algorytmów cyfrowych i uzyskania obrazów o wysokiej dynamice kontrastu i barw (HDR) nie przyniosły spodziewanych efektów (rysunki 6-13). Do wykonania zdjęć jednoczesnych konieczne jest użycie kilku kamer, które muszą być przesunięte względem siebie. Takie rozwiązanie uniemożliwia bezpośrednie użycie algorytmów zwiększających dynamikę tonalną i barwową obrazu. Proste algorytmy dopasowania zdjęć nie radzą sobie w stopniu wystarczającym. Specjalne kadrowanie zdjęć przynosi poprawę sytuacji tylko pozornie. Pomimo znacznie lepszego dopasowania - zamiast zwiększenia jakości sygnału użytecznego (tj. obrazu płomienia), który ma podlegać dalszej obróbce i analizie, uzyskano jego zniekształcenie. Algorytmy HDR zniekształciły obraz płomienia zarówno pod względem jego geometrii, jak też pod względem barw oraz zatarły cechy poszczególnych stref (brak widocznego rozdzielenia stref płomienia). Na fotografiach wynikowych pojawiły się widoczne strefy, dla których brak jest jakiegokolwiek uzasadnienia fizycznego (jaśniejsze dolne części płomienia).

\section{Filtry optyczne, kamera CCD}

Po analizie wcześniej wykonanych obrazów stwierdzono, że:

- geometria płomienia na zarejestrowanym obrazie różni się znacząco od płomienia widzianego ludzkim okiem. Obwiednia i pole powierzchni zarejestrowanego płomienia jest zazwyczaj większe, zwłaszcza w przypadku płomieni większych mocy. Może to być skutkiem sposobu działania migawki stosowanych aparatów i kamer;

- prześwietlenia spowodowane są zbyt dużym natężeniem promieniowania, na które reagują przetworniki kamer. Sensory te wykazują również czułość w zakresie promieniowania ultrafioletowego i podczerwonego (zakresów niewidocznych dla ludzkiego oka);

- na obrazach widoczne są prześwietlenia od części palnika i innych elementów na scenie, które odbijają padające światło płomienia.

Do kolejnych eksperymentów wybrano kolorową kamerę przemysłową z przetwornikiem 1/3 Sony Super HAD HQ1 DSP CCD. Wybór był podyktowany następującymi cechami kamery. Po pierwsze, przetworniki CCD, z powodu zastosowanej technologii elementów światłoczułych, działają na zasadzie migawki global shutter. Po drugie, kamera wyposażona jest w obiektyw umożliwiający dokładną regulację ostrości, w przesłonę i funkcję zoom, co rekompensuje mniejszą rozdzielczość rejestrowanego obrazu. W celu zmniejszenia pasma promieniowania czułości przetwornika, a co za tym idzie - zwiększenia dynamiki tonalnej i barwnej rejestrowanych obrazów, zastosowano filtr UV/IR Cut 1,25" blokujący nadfiolet i podczerwień. W celu zmniejszenia wpływu światła odbitego wykorzystano filtr polaryzacyjny. Oba filtry ograniczyły również natężenie światła padającego na przetwornik kamery. 

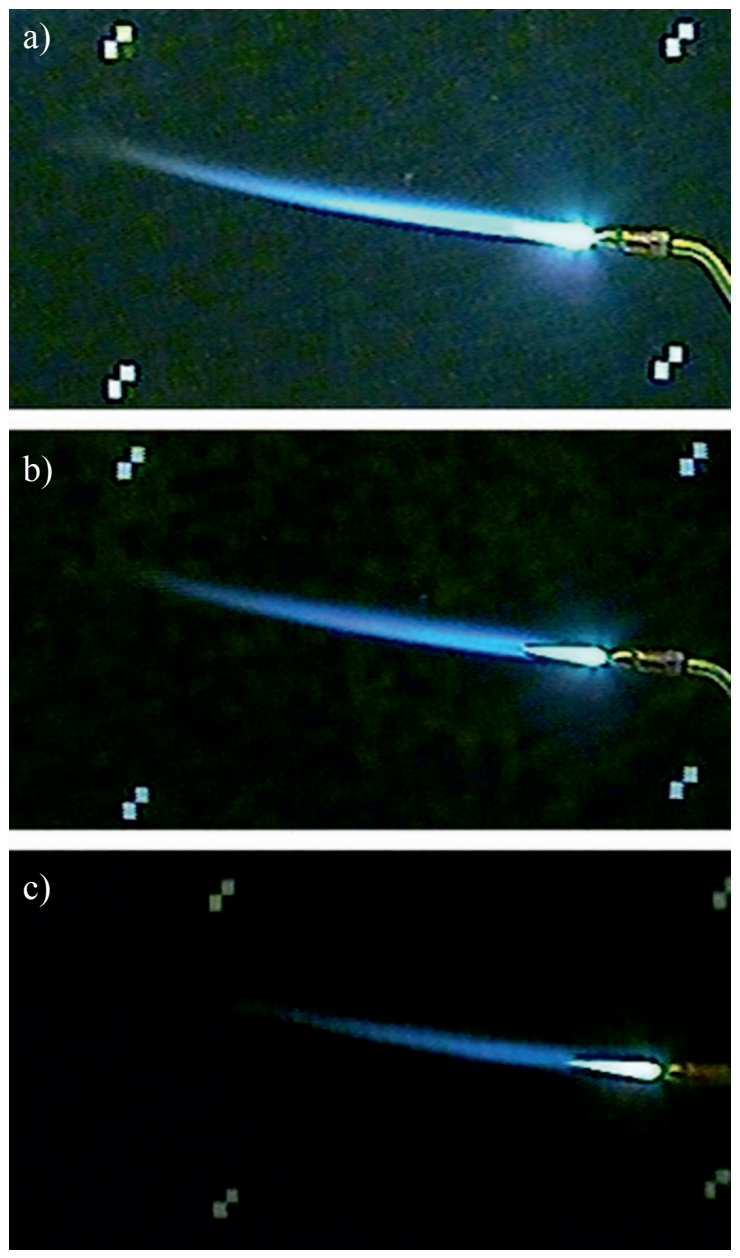

Rys. 14. Kamera CCD - zdjęcia płomienia - stosunek ilości tlenu do gazu palnego: $\frac{\mathrm{O}_{2}}{\mathrm{C}_{2} \mathrm{H}_{2}} \approx 0,8$ : a) bez filtrów optycznych; b) z filtrem POLARYZACYJNYM i IR/UV cut; c) z filtrem POLARYZACYJNYM i IR/UV cut oraz regulacją za pomocą przesłony

Fig. 14. CCD camera - flame images - ratio of oxygen to fuel gas: $\frac{\mathrm{O}_{2}}{\mathrm{C}_{2} \mathrm{H}_{2}} \approx 0.8$ : a) without optical filters; b) with a POLARIZING filter and an IR/UV cut filter; c) with POLARIZING filter and IR/UV cut filter and adjustment by iris

Przedstawione wyżej przykłady pokazują, że użycie filtrów pozwala pozbyć się prześwietleń, zwiększając dynamikę tonalną i barwną na obrazie płomienia. Jednocześnie filtry przyciemniają obraz tła, zwiększając kontrast pomiędzy obiektami tła a płomieniem. Cecha ta może okazać się bardzo pożądana przy dalszej obróbce obrazu ze względu na półprzeźroczystość płomienia.

\section{Wnioski}

Biorąc pod uwagę informacje zawarte w publikacji Kuo (2005) oraz przeprowadzone obserwacje, można stwierdzić, że przedstawiony uproszczony model obrazu płomienia ma odwzorowanie w rzeczywistości. Widoczność poszczególnych stref oraz sposób ich reprezentacji zależą od rodzaju użytego paliwa, a uściślając - od jego szybkości spalania oraz osiąganej temperatury płomienia. W przypadku acetylenu, który ma większą szybkość spalania, a temperatura płomienia acetylenowego jest większa względem propanu-butanu i metanu, zarejestrowany obraz płomienia różni się znacząco. Wynika to głównie z natężenia promieniowania, które pada na przetwornik kamery.

Zarejestrowany obraz zależy od rodzaju użytego przetwornika, w który wyposażone jest urządzenie rejestrujące zdjęcia lub filmy. Kamery mogą rejestrować znacząco inne obrazy tego samego płomienia, w tym również wielkości widocznych na zdjęciach stref płomienia oraz jego cechy charakterystyczne, np. intensywność świecenia lub kolor. Inaczej obraz tego samego płomienia „zobaczy/zarejestruje” przetwornik rejestrujący spektrum UV i światła widzialnego, inaczej przetwornik rejestrujący tylko światło widzialne, inaczej rejestrujący spektrum podczerwieni, a jeszcze inaczej człowiek obserwujący płomień gołym okiem lub wyposażony w filtry, np. okulary spawalnicze.

Z powodu zasady działania kamery termowizyjnej, tzn. rejestracji natężenia promieniowania temperaturowego z powierzchni badanego obiektu, niemożliwa jest ocena stożków widocznych w objętości płomienia w świetle widzialnym. Wszystkie obecnie produkowane kamery termowizyjne są tak przygotowane, aby działały w zakresach fal, w których transmisja przez atmosferę jest jak największa. Ze względu na to z zakresu działania kamer wycięte są te częstotliwości, w których największą wartość absorpcji i emisji promieniowania mają związki najpowszechniej występujące w powietrzu, w tym również para wodna i tlenek węgla(IV). Te dwa związki chemiczne są głównymi składnikami spalin płomieni gazów węglowodorowych. $\mathrm{Z}$ tych dwóch powodów kamery termowizyjne nie nadają się do oceny jakości płomienia palników z otwartym płomieniem.

Stosowany do rejestracji obrazów płomienia palnika przetwornik kamery powinien działać w zakresie promieniowania widzialnego. Jeśli pasmo czułości przetwornika jest szersze, należy zastosować odpowiednie filtry zawężające pasmo. W celu likwidacji odblasków na zdjęciu należy wykorzystać filtr polaryzacyjny. Migawka stosowanego w kamerze przetwornika powinna działać w trybie global shutter.

Artykuł powstał na podstawie pracy statutowej pt.: Systemy rozpoznawania obrazu w uktadach sterowania palnikami gazowo-tlenowymi - badania wstępne - praca INiG - PIB na zlecenie MNiSW; nr zlecenia: 0113/GU/2017, nr archiwalny: DK-4100-100/2017, oraz badań własnych autora. 


\section{Literatura}

Basiura M. (kier. zespołu), 2014. Metody rozpoznawania obrazów w procesie oceny jakości spalania paliw gazowych. Identyfikacja cech obrazu płomienia w pasmie podczerwonym. Archiwum Instytutu Nafty i Gazu - Państwowego Instytutu Badawczego, Kraków.

Basiura M., 2015. Próba wykorzystania metod rozpoznawania obrazów do oceny jakości spalania gazu. Nafta-Gaz, 5: 314-319.

Basiura M. (kier. zespołu), 2017. Systemy rozpoznawania obrazu w układach sterowania palnikami gazowo-tlenowymi - badania wstępne. Archiwum Instytutu Nafty i Gazu - Państwowego Instytutu Badawczego, Kraków.

Convington M.A., 2018. Practical Amateur Astronomy. Digital SLR Astrophotography. Cambridge University Press.

Cyganek B., 2013. Object Detection and Recognition in Digital Images: Theory and Practice. Wiley. ISBN: 978-0-470-97637-1.

Cyganek B., Basiura M., 2017. Real-Time Vision Based System for Measurement of the Oxyacetylene Welding Parameters. ICCSA, 1: 621-632.

Gebhardt Z., 1983. Wpływ parametrów substratów na wypływie z palnika typu rura w rurze na emisyjność dyfuzyjnych płomien gazu ziemnego. Praca doktorska, Politechnika Slaska, Gliwice.

Kołomański S., 2012. Zanieczyszczenie światłem i ciemność. 12. European Symposium for the Protection of the Night Sky.

Kordylewski W. (red.), 2005. Spalanie i paliwa. Wyd. 4 popr. i uzup. Oficyna Wydawnicza Politechniki Wrocławskiej, Wrocław.

Kossowski T., Stasiński R., 2012. Tani sprzęt dla astrofotografii. Poznańskie Warsztaty Telekomunikacyjne.

Kruczek T., 2013. Parametry techniczne kamer termowizyjnych i ich znaczenie w diagnostyce instalacji. Instalator Polski, 7-8: 34-37.

Kuo K.K., 2005. Principles of combustion. John Wiley \& Sons, New York.

Lipczyński J., Okołowicz M., Olczak S., Rybka E., 1984. Tablice matematyczne, fizyczne, chemiczne i astronomiczne. Wydawnictwo Szkolne i Pedagogiczne, Warszawa.

Machinery HDR Effects. <http://www.machineryhdr.com/pl> (dostęp: 6.09.2019).

Nadziakiewicz J., 1989. Teoretyczno-eksperymentalny model radiacyjnego przepływu ciepła w płomieniu gazowym. Praca habilitacyjna, Zeszyty Naukowe Politechniki Ślaskiej. Energetyka, z. 105, Zeszyty Naukowe Politechniki Ślaskiej Nr 984, Gliwice.

Parzych J., Hulewicz A., Krawiecki Z., 2017. Matryce światłoczule - właściwości, parametry, zastosowania. Poznań University of Technology Academic Journals. Electrical Engineering, 92: 189-203.

Popowicz A., 2011a. Analiza prądu ciemnego w matrycach CCD. Przeglad Elektrotechniczny, 4: 260-263.

Popowicz A., 2011b, Metoda korekcji prądu ciemnego w matrycach CCD. Przeglad Elektrotechniczny, 11: 318-320.

Siuda T., 2014. Pomiar zużycia gazu płynnego termicznym przepływomierzem masowym i bębnowym gazomierzem mokrym. Nafta-Gaz, 7: 444-456.

Tadeusiewicz R., Flasiński M., 1991. Rozpoznawanie obrazów. $P W N$, Kraków.

Wojtowicz R. (kier. zespołu), 2010. Wpływ składników gazu ziemnego wysokometanowego (etanu i propanu) na jakość spalania w palnikach kuchni gazowych. Analiza porównawcza teoretycznych metod oceny wymienności z wynikami pomiarów. Archiwum Instytutu Nafty i Gazu - Państwowego Instytutu Badawczego, Kraków.

Wojtowicz R. (kier. zespołu), 2011. Wpływ składników gazu ziemnego wysokometanowego (etanu i propanu) na jakość spalania w kotłach gazowych i gazowych przepływowych ogrzewaczach wody - analiza porównawcza teoretycznych metod oceny wymienności z wynikami pomiarów. Archiwum Instytutu Nafty i Gazu - Państwowego Instytutu Badawczego, Kraków.

Wojtowicz R., 2013. Ocena gazu granicznego G21 pod kątem jego przydatności do określania jakości spalania gazów ziemnych wysokometanowych pochodzących z regazyfikacji LNG w urządzeniach użytku domowego. Nafta-Gaz, 8: 599-612.

Wojtowicz R., 2016. Analiza przyczyn rozbieżności określania wymienności paliw gazowych za pomoca metod teoretycznych oraz na drodze eksperymentalnej. Nafta-Gaz, 6: 422-430. DOI: 10.18668/NG.2016.06.05.

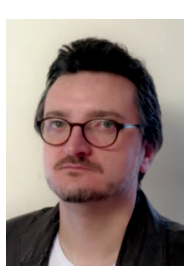

Mgr inż. Maciej BASIURA

Asystent w Laboratorium Badań Urządzeń Gazowych i Grzewczych w Zakładzie Użytkowania Paliw Instytut Nafty i Gazu - Państwowy Instytut Badawczy ul. Lubicz 25 A

31-503 Kraków

E-mail: maciej.basiura@inig.pl 